\title{
PENEGAKAN HUKUM TERHADAP NARAPIDANA YANG MELAKUKAN TRANSAKSI NARKOTIKA DI DALAM LEMBAGA PEMASYARAKATAN
}

\author{
I Made Dwi Payana, Ida Ayu Putu Widiati, Ni Made Sukaryati Karma \\ Fakultas Hukum Universitas Warmadewa, Denpasar - Bali, Indonesia \\ madeyana2851@gmail.com
}

\begin{abstract}
Abstrak
Transaksi narkotika atau peredaran narkotika terutama di lembaga pemasyarakatan marak terjadi. Hal ini merupakan dampak dari hilangnya kontrol sistem yang ada. Kondisi tersebut berdampak pada terbentuknya pandangan negatif masyarakat terhadap pelaksanaan penegakan hukum terutama di lingkungan institusi pemasyarakatan. Penelitian ini bertujuan untuk menganalisis pengaturan sanksi terkait transaksi narkotika yang terjadi di dalam lembaga pemasyarakatan dan menganalisis penegakan hukum terhadap narapidana yang melakukan transaksi narkotika di dalam lembaga pemasyarakatan. Penelitian ini menggunakan metode penelitian hukum normatif empiris (mix method) dengan data primer bersumber dari Lembaga Pemasyarakatan Kelas II A Kerobokan. Teknik pengumpulan menggunakan wawancara. Hasil penelitian menunjukkan bahwa pengaturan sanksi terhadap narapidana yang melakukan transaksi narkotika didalam lapas yaitu ancaman hukuman mati, pidana penjara seumur hidup, pidana penjara paling lama 20 tahun dan paling singkat 5 tahun. Sedangkan penegakan hukum di lembaga pemasyarakatan yaitu hukuman disiplin tingkat berat, dimasukkan ke register, dijatuhkan register $\mathrm{F}$, semua hak-hak narapidana akan hilang, dan diteruskan kepada instansi yang berwenang. Pemerintah, dalam hal ini Kementrian Hukum dan Hak Asasi Manusia, sebaiknya selalu melakukan kerjasama dengan pihak Badan Narkotika Nasional dengan cara mengunjungi secara rutin lembaga pemasyarakatan yang diduga atau patut diduga sebagai tempat transaksi ataupun peredaran narkotika. Kemudian berkenaan dengan produk perundang-undangan yang sudah berlaku sebaiknya perlu diperhatikan kembali.
\end{abstract}

Kata Kunci: Lembaga Pemasyarakatan; Narapidana; Penegakan Hukum; Transaksi Narkotika

\begin{abstract}
Narcotics transactions or narcotics distribution, especially in correctional institutions, are rife. This is the impact of the loss of control of the existing system. This condition has an impact on the formation of a negative view of the community on the implementation of law enforcement, especially in the prison environment. This study aims to analyze the regulation of sanctions related to narcotics transactions that occur within prisons and analyze the law enforcement of prisoners who carry out narcotics transactions in prison. This study uses an empirical normative legal research method (mix method) with primary data sourced from Class II Penitentiary Kerobokan. The technique of data collection used is interview. The results showed that the regulation of sanctions against prisoners who carry out narcotics transactions in prisons, namely the threat of capital punishment, life imprisonment, maximum imprisonment of 20 years and a minimum of 5 years. Whereas law enforcement in correctional institutions, namely severe disciplinary penalties, entered into a register, dropped $F$ register, all prisoners' rights will be lost, and passed on to the competent authority. The government, in this case the Ministry of Law and Human Rights, should always collaborate with the National Narcotics Agency by regularly visiting correctional institutions that are suspected or should be suspected as places for transactions or trafficking of narcotics. Then with regard to legislation products that are already in force it should be noted again.
\end{abstract}

Keywords: Correctional Institutions; Narcotics Transactions; Law Enforcement; Prisoners, 


\section{PENDAHULUAN}

Sistem pemidanaan di Indonesia masih menjadi suatu masalah dalam bidang hukum yang belum banyak diketahui, sehingga masih banyak yang harus dibenahi dari sistem pemidanaan yang ada di Indonesia. Sistem pemidanaan di lembaga pemasyarakatan (lapas) masih kurang mendapat perhatian khusus dari berbagai pihak, baik dari Kementrian Hukum dan Ham ataupun dari lembaga penegak hukum yang juga berperan dalam perbaikan kinerja dari pihak lembaga pemasyarakatan.

Peredaran narkotika atau transaksi narkotika semakin merajalela terjadi bukan hanya dikalangan masyarakat, namun transaksi narkotika juga sering terjadi di lembaga pemasyarakatan. Ini sejalan dengan (King, 2014) bahwa Menekan lalu lintas narkotika narkoba dengan sanksi pidana adalah inovasi yang relatif baru di Amerika Serikat. Narapidana menjadi otak dari transaksi narkotika ini, karena bukan hanya barang terlarang itu dapat masuk ke dalam lembaga pemasyarakatan namun juga narapidana yang sedang melaksanakan hukuman pidana tersebut dapat melakukan transaksi narkotika dengan menggunakan ponsel atau handphone. Dengan kasus yang sama, narapidana narkotika dengan kategori bandar dan pengedar mengetahui adanya aturan khusus tentang perlakuan narapidana narkotika resiko tinggi meskipun tidak terlaksana di Lapas umum Pekanbaru Riau, sehingga karena itu perilaku narapidana narkotika kategori bandar dan pengedar melakukan kesepakatan-kesepakatan informal dengan petugas Lapas Kelas IIA Pekanbaru dalam mengatasi pemenuhan kebutuhan mereka (Novarizal, n.d.). Lembaga pemasyarakatan adalah Unit Pelaksana Teknis (UPT) di bawah naungan Direktorat Jenderal Pemasyarakatan Kementrian Hukum dan HAM. Penghuni di dalam lembaga pemasyarakatan bisa disebut dengan narapidana (napi) atau yang masih berstatus tahanan. Tahanan merupakan orang yang sedang menjalani proses dari pengadilan serta belum dinyatakan bersalah atau tidak bersalah yang ditentukan memelalui putusan hakim.

Pembinaan di dalam lembaga pemasyarakatan tidak selalu berjalan dengan baik sesuai teori dan aturan-aturan yang berlaku. Banyak kendala yang sering dihadapi didalam proses pembinaan terhadap narapidana tersebut. Narapidana terkadang jenuh dan bosan terhadap pembinaan yang dilakukan di lembaga pemasyarakatan. Hal ini dikarenakan terlalu lamanya mereka menjalani hukuman di dalam lembaga pemasyarakatan, sehingga menjadi pemicu mereka melakukan pelanggaran-pelanggaran didalam menjalani hukuman pidana di lembaga pemasyarakatan seperti halnya transaksi narkotika atau peredaran narkotika. Sanksi pidana yang diterapkan di lembaga pemasyarakatan bersifat memperkokoh norma-norma hukum pidana masih jarang dilakukan, sehingga pembahasan dari seluruh hukum pidana masih belum bisa dikatakan serasi (Purnomo, 1999). Didalam menjalankan hukuman pidana di lembaga pemasyarakatan banyak terjadi kendala, seperti kondisi lembaga pemasyarakatan yang memprihatinkan dan hambatan di dalam proses narapidana. Adapun beberapa penelitian yang telah dilakukan sebelumnya yang berhubungn dengan penelitian saat ini. Pertama, (Sadhewo, 2017; Deka, Lestiawati, \& Bram, 2019) menyatakan bahwa ada 2 upaya yang dilakukan untuk penegakkan hukum peredaran narkoba yaitu upaya preventif meliputi: memaksimalkan penggeledahan dipintu pengamanan utama, penindakan tegas kepada pengunjung maupun warga binaan dan upaya represif adalah upaya berupa penjatuhan atau pemberian sanksi. Kedua, (Weisner, Otto, Adams, \& Reichert, 2020) mengatakan bahwa negara-negara pedesaan Illinois menggunakan sistem peradilan lebih dari sekadar kasus masa percobaan dan penerimaan dan keluar penjara. Selanjutnya, (Winterdyk \& Ruddell, 2010) menyatakan bahwa kurangnya peluang rehabilitasi bagi anggota geng merupakan satu kekurangan dalam berbagai strategi manajemen geng di sebagian besar wilayah hukum.

Dalam penelitian yang lain, (Iriani, 2019) mengatakan bahwa hukuman yang diberikan kepada Napi wanita berkisar 3 bulan 9 bulan kurungan penjara, setelah dipotong masa tahanan menjadi 1-3 bulan masa tahanan. Proses pembinaan di lapas Ponorogo sudah berjalan secara baik, hanya saja proses pembinaan tersebut belum sampai pendampingan sampai keluarnya narapidana. Berdasarkan uraian latarbelakang diatas, maka penelitian membahas bagaimana pengaturan sanksi terkait transaksi narkotika di dalam lembaga pemasyarakatan dan bagaimana penegakan hukum terhadap narapidana yang melakukan transaksi narkotika di dalam lembaga pemasyarakatan.

\section{METODE}

Penelitian ini menggunakan metode penelitian hukum normatif empiris (mix method). Dalam penelitian ini juga menggunakan teknik wawancara. Data yang digunakan adalah data primer yang bersumber dari Lembaga Pemasyarakatan Kelas II A Kerobokan. Selain itu, data sekunder diambil dari dokumen 
seperti Jurnal, kamus dan buku penelitian lainnya. Kemudian data yang diperoleh dianalisis dengan menggunakan teknik descripsi.

\section{HASIL DAN PEMBAHASAN \\ Pengaturan sanksi terkait transaksi narkotika yang terjadi di dalam lembaga pemasyarakatan}

Transaksi narkotika yang terjadi di dalam lembaga pemasyarakatan merupakan tindak pidana khusus. Berdasarkan tindak pidana khusus, maka hakim dipersilahkan atau diperbolehkan untuk memutus 2 (dua) pidana pokok sekaligus. Hukuman yang diperoleh adalah hukuman badan dan denda, yang termasuk hukuman badan yaitu, pidana mati, pidana seumur hidup, serta pidana penjara tertentu berdasarkan putusan pengandilan (Moeljatno, 2003). Pemidanaan itu bertujuan untuk memberatkan pelaku serta memberikan efek jera terhadap pelaku kejahatan narkotika agar dapat diantisipasi di masyarakat. Sebab tindak pidana narkotika sangat merusak citra dan membahayakan kepentingan bangsa dan negara.

Narkotika itu sendiri merupakan obat atau zat yang berasal dari bukan tanaman ataupun dari tanaman, baik semisintetis maupun sintetis, yang dapat menyebabkan perubahan kesadaran atau penurunan kesadaran, dapat menghilangkan rasa nyeri, serta dapat menyebabkan sindrome ketergantungan (Iskandar, 2019). Pengertian narkotika ini juga dipertegas dalam Pasal 1 Angka 1 Undang-Undang Narkotika. Narkotika memiliki berbagai macam jenis-jenis narkotika, yaitu diantaranya:

- Morphin, merupakan alkoholoida yang utama dari opium.

- Opium, merupakan getah yang memiliki warna putih susu yang keluar dari kotak biji tanaman vervum samni yang belum maupun yang sudah matang.

- Kokain merupakan tanaman berbagai genis erithoxylon tanaman eryhroclacea yang apabila dikeringkan atau sudah dalam bentuk serbuk maka menghasilkan kokain secara langsung.

- Heroin, merupakan diacethyl morphin dari zat semi syntetis turunan dari morphin tersebut.

- Mariyuana atau ganja, merupakan tanaman genus cannabis yang diambil damar, termasuk buah dan bijinya kemudian pengolahanny menggunakan damar untuk dasar, bentuknya seperti telapak tangan dan selalu ganjil.

- Sabu-sabu, berbentuk kristal-kristal kecil yang berwarna putih, seperti bumbu masak, tidak berbau, dan mudah larut didalam alcohol.

Dari beberapa jenis-jenis narkotika diatas maka narkotika digolongkan menjadi 3 golongan, yaitu Golongan I, Golongan II, dan Golongan 3 (Hamzah \& Goenanti, 2011) yang termasuk Golongan I adalah opium, morphin, serta heroin, kemudian Golongan II adalah ganja, sabu-sabu, ekstasi, serta hashis, selanjutnya Golongan III adalah sejenis minuman yang terkandung alcohol didalamnya seperti, vodka, wine, beer, whisky.

Transaksi narkotika atau peredaran narkotika yang terjadi di dalam lembaga pemasyarakatan sudah sangat marak. Transaksi narkotika didalam lembaga pemasyarakatan merupakan peredaran gelap narkotika yang dilakukan secara melawan hukum dan tanpa hak untuk melakukan peredaran narkotika. Peredaran narkotika di dalam lembaga pemasyarakatan merupakan kejahatan luar biasa (extra ordinary cryme) dengan sistem jaringan yang rumit. Kondisi tersebut mengakibatkan masyarakat berpandangan negatif terhadap pelaksanaan yang berkaitan dengan penegakan hukum di lingkungan lembaga pemasyarakatan.

Pengaturan sanksi terkait transaksi narkotika atau peredaran narkotika telah diatur dalam beberapa ketentuan peraturan perundang-undangan diindonesia, antara lain tercantum dalam UndangUndang Narkotika, Permen Hukum dan Ham tentang tata tertib lembaga pemasyarakatan dan rumah tahanan negara, dan Peraturan Pemerintah tentang pembinaan dan pembimbingan warga binaan pemasyarakatan. Dimana sanksi yang didapat oleh narapidana yang melakukan transaksi narkotika di dalam lembaga pemasyarakatan dapat dikenakan sanksi hukuman berupa, pidana mati, penjara seumur hidup, penjara paling lama 20 (dua puluh) tahun, dan paling singkat 5 (lima) tahun, serta narapidana akan dikembalikan kepada instansi berwenang karena telah melalukan pelanggaran berat di dalam lembaga pemasyarakatan. Sanksi ini tentunya disesuaikan terhadap unsur-unsur tindak pidana yang dilanggar oleh si pelaku. 
Pelaku kejahatan yang divonis penjara akan ditempatkan di lembaga pemasyarakatan, lembaga ini merupakan institusi teknik di jajaran Kementrian Hukum dan Ham. Lembaga pemasyarakatan menjadi tempat untuk memasyarakatkan kembali setiap orang yang telah melakukan kejahatan. Ada 3 (tiga) pokok tujuan utama yang ingin dicapai terhadap pemidanaan, yaitu memperbaiki kepribadian dari penjahat itu sendiri, membuat pelaku kejahatan menjadi jera dalam melakukan suatu kejahatan, dan membuat penjahat atau pelaku kejahatan menjadi tidak mampu melkukan kejahatan yang sama ataupun kejahatan yang lain, yang dengan cara-cara lain sudah tidak dapat diperbaiki lagi (Lamintang, 2010).

Fungsi lembaga pemasyarakatan terkhusus Lembaga Pemasyarakatan Kelas II A Kerobokan Bali dari hasil wawancara dengan Bapak Dewa Gede Astara (selaku pelaksana tugas Kepala Lembaga Pemasyarakatan Kelas II A Kerobokan) bahwa fungsi lembaga pemasyarakatan di kerobokan ini ada 2 (dua), yaitu berfungsi sebagai lembaga pemasyarakatan dan rumah tahan negara. Dikarenakan kabupaten Badung dan Kota Denpasar sampai saat ini belum memiliki Rumah Tahanan, sehingga Lembaga Pemasyarakatan Kelas II A Kerobokan ini memiliki dua fungsi. Selanjutnya fungsi utama dari lembaga pemasyarakatan ini ialah warga binaan pemasyarakatan disiapkan untuk dapat berintegrasi secara baik dengan masyarakat, dan dapat berperan aktif kembali sebagai anggota masyarakat diwilayah mereka masing-masing, serta bertanggungjawab, kemudian yang tidak kalah pentingnya adalah dari fungsi lembaga pemasyarakatan ini adalah untuk memberikan efek jera bagi narapidana khususnya dalam tindak pidana narkotika, agar tidak mengulangi kembali kejahatan yang sama ataupun melakukan kejahatan atau tindak pidana lainnya sehingga mengurangi tingkat residivis terkhusus dalam tindak pidana narkotika.

Faktor penyebab narapidana melakukan transaksi narkotika di dalam lembaga pemasyarakatan berdasarkan hasil wawancara dengan Bapak Eries Sugiyanto (selaku Kasie Keamanan Lembaga Pemasyarakatan Kelas II A Kerobokan), faktor penyebabnya antara lain:

1. Personil

Kurangnya jumlah personil dalam bidang keamanan yang langsung berhadapan dengan narapidana menjadikan peluang bagi narapidana melakukan tindakan transaksi ataupun penggunaan narkotika di dalam lembaga pemasyarakatan. Diketahui bahwa jumlah penghuni Lembaga Pemasyarakatan Kelas II A Kerobokan tertanggal 29 Oktober 2019 berjumlah 1637 orang, sedangkan jumlah personil dalam bidang keamanan hanya berjumlah 6 orang. Sudah jelas dengan 6 orang ini tidak mungkin melakukan pengawasan terhadap seluruh narapidana secara kondusif dan maksimal.

2. Peningkatan SDM Petugas Lapas

Petugas yang berada dalam Lembaga Pemasyarakatan Kelas II A Kerobokan masih belum sepenuhnya memiliki SDM yang baik sesuai dengan kinerja mereka selaku petugas, sehingga sangat perlu untuk melakukan peningkatan SDM terhadap seluruh petugas lembaga pemasyarakatan guna tercapainya suatu program kerja yang maksimal.

3. Alat Pendeteksi Sinyal

Dalam Lembaga Pemasyarakatan Kelas II A Kerobokan hingga saat ini belum memiliki alat pendeteksi sinyal yang digunakan untuk melacak barang-barang terlarang seperti narkotika dan psikotropika.

4. Penempatan Narapidana

Penempatan narapidana di dalam Lembaga Pemasyarakatan Kelas II A Kerobokan ini bisa dibilang keliru karena narapidana dengan kasus narkotika dimasukkan dalam satu sel. Hal ini yang membuat mereka bisa saling tukar wawasan dan pengalaman tentang narkotika, sehingga tidak heran jika setelah mereka bebas dari lembaga pemasyarakatan bukannya menjadi jera namun karena jejaring narkotika sudah banyak diketahui ketika berada didalam lembaga pemasyarakatan, mantan narapidana ini malah semakin ahli dalam mengendalikan narkotika diluar sana.

5. Kapasitas Berlebih

Kapasitas berlebih ini menjadikan kesulitan bagi petugas untuk menempatkan narapidana di dalam sel. Sehingga selain mereka dapat berkumpul dalam satu sel, hal ini juga menjadikan narapidana dapat melakukan transaksi narkotika ketika mereka berada jauh dari para petugas keamanan lembaga pemasyarakatan.

6. Sebagai Mata Pencaharian 
Faktor narapidana melakukan transaksi atau peredaran narkotika ini dianggapnya sebagai mata pencaharian adalah hal yang paling banyak ditemui di lembaga pemasyarakatan khususnya Lembaga Pemasyarakatan Kelas II A Kerobokan. Mereka selalu menganggap bahwa kerja yang tidak berat namun hasilnya memuaskan menjadikan mereka menganggap bahwa dengan melakukan transaksi narkotika atau peredaran narkotika ini dapat menunjang perekonomian dari keluarga mereka.

\section{Penegakan hukum terhadap narapidana yang melakukan transaksi narkotika di dalam lembaga pemasyarakata}

Penegakan hukum terhadap narapidana yang melakukan transaksi narkotika di dalam Lembaga Pemasyarakatan, yaitu dikenakan hukuman tingkat berat, kemudian dimasukkan ke register, dijatuhkan register $\mathrm{F}$, semua hak hilang (asimilasi, remisi, cuti mengunjungi keluarga, cuti bersyarat, pembebasan bersyarat, dan cuti menjelang bebas), dan meneruskan kepada instansi berwenang. Meneruskan kepada instansi yang berwenang dalam hal ini dilimpahkan ke instansi kepolisian dan ditindaklanjuti oleh para penyidik kepolisian. Alur atau proses pemeriksaan terhadap pelaku setelah diserahkan oleh pihak lembaga pemasyarakatan, yaitu penerimaan laporan, melakukan penyelidikan, pengumpulan barang bukti, melakukan penyidikan, membuat berita acara pemeriksaan (BAP), kemudian pelimpahan berita acara pemeriksaan (BAP) kepada kejaksaan. Tindak pidana narkotika dilakukan upaya penegakan hukum dengan upaya represif. Upaya hukum refresif merupakan upaya penegakan hukum terhadap gangguan nyata atau ancaman faktual berupa pemberantasan, penindakan, dan penumpasan sesudah terjadinya atau memberikan contoh sosial learning serta mengakibatkan efek deterrence supaya mengantisipasi para pelaku kejahatan agar tidak mengulangi kembali perbuatannya. (Rumadan, 2013) mengatakan dalam penelitiannya bahwa orientasi penegakan hukum pidana tidak semistinya berakhir pada penjatuhan sanksi pidana berupa penjara terhadap terdakwa, namun penjatuhan sanksi berupa sanksi sosial terhadap terdakwa dengan skala tindak pidana yang rekatif ringan perlu untuk dikedepankan atau diutamakan melalui pendekatan restoratif justice.

\section{KESIMPULAN}

Dari hasil penelitian dan pembahasan tentang pengaturan sanksi dan penegakan hukum terhadap narapidana yang melakukan transaksi narkotika di dalam lembaga pemasyarakatan, maka dapat disimpulkan bahwa pertama: perkenaan dengan pengaturan sanksi terkait transaksi narkotika di dalam lembaga pemasyarakatan, yaitu pelaku dapat dikenakan sanksi berupa ancaman hukuman pidana mati, penjara seumur hidup, penjara paling singkat 5 (lima) tahun dan paling lama 20 (dua puluh) tahun, serta pidana denda paling sedikit satu miliar rupiah dan paling banyak sepuluh miliar rupiah sesuai dengan ketentuan pasal 114 Undang-undang Narkotika. Selanjutnya, diteruskan kepada pihak berwenang sesuia dalam ketentuan Pasal 17 Permen Hukum dan Ham Nomor 6 Tahun 2013. Hasil ini sejalan dengan (Suhayati, 2015) bahwa percepatan pelaksanaan hukuman mati bagi terpidana mati kasus peredaran gelap narkoba oleh Kejaksaan. Vonis pidana mati dimaksudkan untuk menimbulkan efek jera terhadap pelaku peredaran gelap narkoba. Kedua, terhadap narapidana yang telah melakukan transaksi narkotika di dalam lembaga pemasyarakatan akan dilakukan penegakan hukum yaitu, hukuman disiplin (tingkat berat), dimasukkan ke register, dijatuhkan ke register F, semua hak hilang, diteruskan kepada instansi berwenang. Selanjutnya penegakan hukum yang dilakukan oleh pihak kepolisian terhadap narapidana yang melakukan transaksi narkotika di dalam lembaga pemasyarakatan adalah berupa, menerima laporan dari pihak lembaga pemasyarakatan, tertangkap tangan, melekukan penyelidikan, pengumpulan barang bukti, melakukan penyidikan, membuat berita acara pemeriksaan (BAP), selanjutnya pelimpahan Berita Acara Pemeriksaan kepada Kejaksaan.

\section{DAFTAR PUSTAKA}

Deka, F., Lestiawati, I., \& Bram, A. M. (2019). Penerapan Sanksi Disiplin Bagi Pelaku Pengedar Narkotika Pada Rumah Tahanan Negara Kelas IIA Palu, (2), 1733-1743.

Hamzah, A., \& Goenanti, B. D. S. M. (2011). Kejahatan Narkotika \& Psikotropika. Jakarta: Universitas Trisakti.

Iriani, D. (2019). Penegakan Hukum dan Kesadaran Hukum Narapidana Wanita di Lapas Ponorogo.

Kodifikasia: Jurnal Penelitian Islam, 13(1), 117-130.

Iskandar, A. (2019). Penegakan Hukum Narkotika. Jakarta: Elex Media Komputindo. 
King, R. (2014). Narcotic Drug Laws and Enforcement Policies. Law and Contemporary Problems, 22(1), 113-131. Retrieved from http://www.jstor.org/stable/1190435

Lamintang. (2010). Hukum Penintensier. Jakarta: Sinar Grafika.

Moeljatno. (2003). Perbuatan Pidana dan Pertanggung jawaban Dalam Hukum Pidana, . Jakarta: Bina Aksara.

Novarizal, R. (n.d.). Narapidana Narkotika di Lembaga Pemasyarakatan Umum: Studi Terhadap Tiga Narapidana Kategori Bandar dan Pengedar di Lapas Kelas IIA Pekanbaru, 13-23.

Purnomo, B. (1999). Pelaksanaan Pidana Penjara Dengan Sistem Pemasyarakatan. Yogyakarta: Liberti.

Rumadan, I. (2013). Problem Lembaga Pemasyarakatan di Indonesia dan Reorientasi Tujuan Pemidanaan. Jurnal Hukum Dan Peradilan, 2(2).

Sadhewo, A. W. (2017). Lembaga Pemasyarakatan (Studi di Lembaga Pemasyarakatan Kelas IIA Padang).

Suhayati, M. (2015). Penegakan Hukum Peredaran Narkoba di Lapas dan Rutan. Info Hukum Singkat, $7(8), 1-4$.

Weisner, L., Otto, H. D., Adams, S., \& Reichert, J. (2020). Criminal Justice System Utilization in Rural Areas. LlIinois Criminal Justice Information Authority.

Winterdyk, J., \& Ruddell, R. (2010). Journal of Criminal Justice Managing prison gangs : Results from a survey of U. S . prison systems is. Journal of Criminal Justice, 38(4), 730-736. https://doi.org/10.1016/j.jcrimjus.2010.04.047 